\title{
Critical Analysis on Death: From Deluded Fancy to Desired Ecstasy
}

\author{
Patrick Neil M. Santiago
}

\author{
Email: patrickneilsantiago1@gmail.com
}

\begin{abstract}
There's no other element or stimulus man can devise to avoid facing his final end. Absurdity occurs by depriving one's happiness and limiting his potentials. Man deeply fettered in his invented fancy and ecstasy leading him to become victim of both selfand preachers. This paper investigated the root of anxiety, way of healing it, process into ecstasy, and man's contribution to the world that appears absurdity. The deluded fancy of man's ecstasy despised his own self, and this makes him absurd. At the end, man was deprived of happiness and a chance to expand his potentials due to deception caused by the prey that made him blinded. The will of extreme preachers to new generation does not contribute to the masses but rather reshape people to be impotent and dull. Keywords-absurdity, anxiety, convalescence, deluded fancy, ecstasy
\end{abstract}

\section{INTRODUCTION}

Life begins to sprout as a morning dew and ends as a vapor evanescently. Paradoxically, its ending accompanies another beginning. The head and tail of life are appointed to its lethargic fall. Reality has shown that no one can escape the terminal fate of mortality. Man is powerless to defy the pois on of death. Indeed, death is the horrible and the most terrible fate of humanity. This is why the life and action of man rely heavily on dealing with limitations of tragic ending. In this regard, the following questions are worth pondering on: What is death? How do anxieties exist in man? How do people deal with their horrible ending- death? What human can contribute over future in his limited and temporary life?

The assumption of most people about the concept of unfathomable death resulted to extreme anguish and tension. But in such what manner does man's anxiousness appear? Dasein or being there is the term that best defines humanity. For the German philosopher Martin Heidegger (1889-1976), human existence is perfectly described as a mode of being rather than to define as a thing. Similarly, when we speak about phobia, it refers to a certain fear to an object. The fear of a spider or a fear of water, for instance, appears as irrational fear on something. Thus, this fear is clearly a psychological state. However, as Heidegger explains, anxiety is not the same as fear.
Anxiety is a state-of-mind that refers to nothing: no-thing and no-where [1]. There is no such object or place to be derived on. Thus, Heidegger's notion on anxiety exhibits the presence of nothingness. Existence is the state of Dasein which is Being-in-the-world. So to the one who has anxiety; Being-in-the-world itself in the face all forms of anxiety is to be in an anxious state [1]. Thus, anxiety is a mode of man's being.

In Heidegger's theory, the intensity of man's anxiety to feel and know that he exists is actually the source of all his anxieties [2]. The entire phenomenon on anxiety lies into man's central concern. Heidegger suggests three fundamental concerns; an ontological entity that generates the state of anxiety namely: facticity, existentiality and fallenness [1]. Facticity is classified as man's past. Though man is thrown into the world, he requires an affirmation of the self; seek for the authenticity to understand his very being. Existentiality is characterized by man's involvement over the future. Hence, man uses his potentials. Obviously, man is born free; [3] possesses freedom and responsibility [2]. He is responsible for his choices and decisions in his every action [2]. Therefore, facticity and existentiality occur to be the past and the future of man. Moreover, fallenness of man concerns about the present condition wherein he is aware of the inevitable loss of unique -authentic self. Hence, man requires a way with regard to loss due to his temporalitylimited existence. Heidegger emphasized on his book that time is the element that limits man, it does matter to his existence. In other words, time is responsible for the occurrence of man's state of anxiety. Man may lead back to ontological facticity as he requires a way that respond to the limitation and temporality. He will tend to create an impossible name and invent deluded fancy that may break the anxiety. As he intends to deny his temporality, he does require a way where convalescent occurs.

\section{METHODOLOGY}

This study uses critical analysis on the delusional beliefs of the masses regarding death. According to [4] "a critical analysis is subjective writing because it expresses the writer's opinion or evaluation of a text which was break down and study the parts". 


\section{CRITICAL ANALYSIS AND EVALUATION} A. Convalescent of Mass

The anxiety of a man about death leads to create convalescence that has been acquired from religious faith particularly Christianity and the like. This convalescence was extremely exaggerated by the new preachers of society spread in some communities that apparently becomes an effective strategy to capture one's sympathy on certain cult. The preaching goes severe and threatens each individual and poisons the minds of the many. But the worse and drastic threat is the reshaping of values leading to absurdity.

Convalescence is simply described as a way to heal man's horrible ending of mortality. It is believed that there is misleading speculative idea on the context of death. Its context has two major consequences namely: physical and spiritual. Similarly, if a man experiences sufferings or frustrations in this physical world, he finds a way that can heal the wounds of his entire being. Hence, he is driven to rely on the belief and teaching of religion that serve as a relief for his pressing anxiety.

In the book of notable German philosopher, Friedrich Nietzsche's (1844-1900), entitled Thus Spoke Zarathustra depicted the deluded fancy beyond mankind [5]. Three of the several topics were Of the Afterworlds men, Of the Despisers of the Body and Of the Preachers of Death. These topics stated a need for convalescence due to the horrible notion of death. On the topic Of the Afterworlds men shows that man had invented a belief- form an imaginary conception of a hope- afterlife. This created an intoxicating joy to everyone which Nietzsche aims to cast. Thus, man created an image of God, a human work and from human madness. This fancy was made to divert man's condition of anxiety. This convalescence [5] eschews man from suffering and tormenting condition as to forget himself through intoxicating joy- awaiting afterlife. However, convalescence misled man in dealing and facing his life in real world. The topic discussed in $O f$ the Despisers of the Body portrays how man ignores and despises the importance of his body brought by the illusion of the said deluded fancy. Man, then tends to follow the invented belief and depriving his body to be instrumental in acquiring intelligence into highest wisdom. It hinders the capabilities of the creative body to perform its innate potential. This phenomenon wastes the purpose of the body. Instead of pursuing the fullest essence of earthy world, man waited for the afterlife. Similarly, on the topic shown in Of the Preachers of Death, man is perceived to have a deep abstinence and deprivation. Hence, preachers just input into the minds of people that physical world is full of superfluous things. In this regard, man hinders himself to be happy. Moreover, preachers corrupted the minds of individuals leading them into laziness rather than being productive.
This forces man to believe that earth gives nothing but sufferings and tormenting life. This idea paints a picture on man's mind to hope for eternal life and imagine a perfect world free from absurdity and all other forms of violence and illnesses.

Socrates expounded that the unexamined life is not worth living [6] while the existentialists emphasized that existence precedes essence [2]. These beliefs evoke something on man's essence and existence. Man has a freewill to strive to the fullest, find meanings, search for truth and fight with honor. In dealing with man's existence, it demands an intensive examination of life as a whole, an opportunity, and a responsibility to capture the essence of life. Man should exercise his capabilities to think, create and value the gift of life from his Creator. He must exercise his understanding as he faces life. The French philosopher Jean-Paul Sartre (1905-1980) described essence as prerequisite to man's past, thus, he postulated that each man could make essence that makes his essence as he lives [7]. The interpretation of the socalled essence depends on the one who tries to discover it. The misconception about death caused by the exaggerated approach of the religious leaders in the community results to this anxiety that leads people to absurdity. To cite an example, the system of religion in the community that presently bursts and expands due to its instinct will continue to fool people. Leaders taught their followers to praise God, to serve in accordance to His will, but people were just deceived by such interpretations and practices, but in reality, it is the will of the predator that reigns and not the will of God. These new leaders of the new generation forcedly dictated their followers to learn their doctrines. Because of the so-called anxiety of death, man created a convalescence that will give a relief in a substance called salvation to believe in life after death. The misinterpretation of this concept leads people to serve and spend their whole life and attention in worshipping the gods of their churches. But where did the fictitious belief root? The Jews are responsible for giving form to the slave fiction [8]. The Judaic priest is the artist genius who brings to the fore the negative premises [9]. The Christian priest continues the legacy of the said Judaic priest like a contagious disease [8]. These beliefs are obviously exaggerated and forged by the new religious sects and they were preached to members. People believe and wait for the "promise" of the second coming of Jesus and this brings them absolute happiness. Through this, people in the community depend much on the legitimation of religion where they are brainwashed to believe and rely much on the narrow concept of faith [8]. This resulted man to hope for salvation. The prey intends not to work for themselves and their family but to spend their whole lives in their chosen religion. The opportunity and responsibility of man in his own self will be lost and 
wasted. From the state of hallucination of the predators, through their exaggerated interpretation, the prey is extremely deprived, hindered and limited of their ambition and will. The time, effort and opportunity were all sacrificed, and all of these are only parts of a man's desire to his neighbor. The anxiety of man about death will lead to despise his own physical body in believing that its existence is not real life.

The invented institutions built by the desire of predators are responsible for the indolence of man. Their invented teachings have poisoned and continuously corrupt the minds and souls of many individuals. Through such factors man has been enslaved of the knowledge imposed to him rather than personal inquiry and critical reasoning he can deliberately do. Under the tongue of sweet report devising the divine teaching, the prey can be easily deceived by the predators. This instance leads to hermit that captures the herd.

According to Nietzsche, existence is one opportunity of man. It is believed that this opportunity should provide chances to fulfill his essence and not to delve in absurd doings. Man must do something and not just to sit down and be fettered by such predators. This is his chance to give essence for his existence. In consonance to this concept, Nietzsche said that:

I wish to speak to the despisers of the body. Let them now learn differently nor teach differently, but only bid farewell to their own bodies and so become dumb.

'I am body and soul' so speaks the child. And why should one not speak like children?

But the awakened, the enlightened man says: I am body entirely, and nothing besides; and soul is only a word for something in the body.

The body is a great intelligence, a multiplicity with one sense, $a$ war and a peace, a herd and $a$ herdsman,

Your little intelligence, my brother, which you call 'spirit', is also an instrument of your body, a little instrument and toy of your great intelligence.

You say 'I' and you are proud of this word. But greater than this although you will not believe in it - is your body and its great intelligence, which does not say 'I' but performs 'I' [5].
Nietzsche underscored that man should exercise his capacity and perform with his physical capability. Existentialists also postulate that man has a responsibility for his own self and to the world he lives in [2]. Now, the physical death is the fate of all men and it is the common ending to all. It does not mean that all must ignore and despise physical body, but all must understand that life has its own limit and it must not be spent only in achieving one's essence but to value life.

\section{B. Religious Ecstasy}

In the foregoing analysis on death we can observe the occurrence of convalescence that had been induced by anxiety. It is crystal clear how people divert angst into a state of extreme delight which is absolute ecstasy. Man created deluded fancy that can be traced from the past and the present religious cult which evolved in the concept of "fancy" and "ecstasy". Fancy involves hope for the illusion of afterlife and lies no assurance in achieving what one wishes because ecstasy involves an actual process that gives immediate relief to anxiety and assurance that one had a strong possibility to acquire salvation. The two are likely the same in terms of the illusion on afterlife, but the developed ecstasy occurs to be more exaggerated and confusing. It does not only cure anxiousness of individual from the notion of death, but it also heals the guilt as cleansing to the conscience of man. This approach will convince oneself to believe that his soul was purified and remove sins through meditations and rituals. In this condition he made no doubt for accepting salvation through purgation.

Rituals or rites might had been originated from certain primitive concept but what we see today particularly to some church activities in the quiet community are being adopted by modern religious cults. Regardless of such matter, the modern man was influenced by the primitive exercises. This primitive ritual evolved and might have been observed in contemporary as activities or fellowship of civilized world. The term cult was defined in a positive manner not as negative or evil act that is in present perception appears a distorted term. Cult refers to a small religious group that is not part of a larger or popular guild like Buddhism, Christianity, Confucianism, Hinduism, Islam, Shintoism and or Taoism. These small groups are very devoted supporters of a certain faith or belief. However, they are considered extremely exaggerated in several manners or approaches in the context of religion. As time passes by, modern religious cults unconsciously flavor their practices by denying the precursor or trailblazer of their guild that instead of giving appreciation, they deeply despise and blaspheme it and became reluctant to accept what is true. They develop distinctive worship mechanisms that eschew into traditional. This method is adopted in the way of Psalm. 
They use peculiar or intense style, using different media that serve as their ways of meditation or worshipping methods of expressing their faith.

Carl Gustav Jung (1875-1961), a Swiss renowned psychiatrist explained the concept between religion and creed. He stated that religion is greatly concerned in building relation while creed is for confession [10]. However, the context of religion is transformed into the context of creed nowadays [11]. Religion shifts from the original approach as a "relation" between man and God into new approach which is about "confession". The term relation for the devotees has been interpreted as literal term for service or duties for their ministries. The deeds that they inserted in their head as they understood their duty or purpose are the works of spreading only the words of God brought by their factions or guild where they belong. They focus and confine the whole scope of their actions in dealing "only" on things far from God and fail to see or give the importance of delving to what is realistic, practical and most sensible way of living. The self being confined in religious guild or cult offers services and sacrifices of one's time with effort for the institution, ministries or leaderships instead of working directly for the greater good of others. Most devotees assume that their deeds for their guild or cult are the deeds offered to God. But in reality, it is just the gods of their guild or cult that are benefited. Instead of giving their deed or share it with the needy, they selfishly and unstoppably coveted all forms of gains they can get from the congregation.

The great majority have shifted their pure intentions to being God's servant to becoming political masters. They choose self-victory that is grounded on selfish desires over pure virtues. The mind has begun to be the only medium of faith that transcends the bridge between man and God. Thus, the "involvement" of man to God turns out to be of repression rather than an actual deed or action. The concept of "deeds" transforms into "perform" [11].

Majority of religious devotees proclaim and preach about God but their lives and way of living never evoke any godly or holy. Their words seem to mismatch with their actions. These devotees and fanatic members of different sects perform, participate and interact intensely in their interfaith services. Their actions are stimulated with passion and associated with extreme emotions. Through their fondness from poisonous resentment, ecstatic interpretations of God's word together with their personal is sues serve to people who have been deceived by such agnostic belief. Their cry creates noise of an anguished soul, their shout and tears sound a desperate self that was blinded by truth and true doctrines. This feature of such activity is characterized by hysteria as their way of expressing their faith. Hysteria is the state of uncontrollable behavior, a burst of hyper emotion endowed by sudden agitation or excitement. The term hysteria is not neurosis or psychological illness but a state of thinking about something, a process that turns consciousness into unconscious state. But how a person or devotee's action can be triggered by such hysteria? Hysteria is induced by music, singing and hand clapping [12]. Jung stated that hysteria is a present religious cult in Tennessee, U.S.A. wherein ceremonies include the handling of a poisonous snake that people pass from hand to another hand in the course of their ceremonial activity and the worse thing out of this practice is that sometimes participants are fatally bitten [12]. Moreover, in connection to the discussion of devotees, one might observe that some communities have peculiar activities that are part of their worship mechanisms. When the music is on, everyone is rejoicing, performing and interacting in the course of what they call worship where singing, dancing and clapping of hands are performed uncontrollably. The ambiance endowed by such method induces everyone to move and agitate emotions leading to hysteria. It is seen more intense and extreme way of worshipping their gods. It is their means of expressing optimistic vibes, relief and great feeling of affirming their faith.

These intense emotions of such devotees ensnare them into trance. Trance is a state of daydreaming. It is a state where one can freely move and respond to the question or commands of the moderator and can command in the same manner. In this state a person is not fully aware of what is happening around him because he is thinking of something that caused to eclipse the conscious mind. Jung stated in his example that the frenzy of a Balinese s word dance causes the dancers to fall into trances and sometimes turn their weapon against themselves. Even the modern rock and roll artists seem to induce an almost comparable trance practicing extreme excitement and unfathomable ecstasy [12].

The devotees who were pitifully described above thought that their ceremonial activities reach God's grace from heaven not realizing that their acts of worship only dog them to pitiful hell. They believed they present themselves to Supreme Being as justified righteous individuals. The extreme mass is drunk of hysteria and is "possessed" with ecstatic spirits [12]. Through their activity, they assumed that they were healed and convinced themselves that have been possessed by the Holy Spirit. They also believe that through noise, God hears them; they perform faith-healing miracles to attract people and lure them to the coated and man-made miracles. These are truly absurd and abominable acts ever done in the sight of God. They thought that they have been blessed, but the reality shows that they are cursed. This feeling is subjective and dominated by hysteria. 
If fancy is man's invented convalescent to relieve him from anxiety, hysteria becomes his method to eschew or divert his anxiety into peculiar activity such as trance to gain satisfaction, gratification and extreme happiness. So, in dealing with one's death, this religious sect will not treat death as a loss but an event of life to celebrate.

\section{Legacy as Essence}

The idea about the concept of essence also addresses the concept of time, death and legacy. Life can be absurd due to failure, frustration and frivolous matters in this physical world. Out of life occur problems, struggles and temptations that are perceived as spices to man's life as he finds and fulfills his very essence. But assumption to absurdity of life does not mean the absence of essence. One must believe that after the end of this temporary life comes an unending existence of essence that is boundless and limitless in all elements of imperfections. Time could limit the existence of things, man's being and probably his legacy, but it couldn't be just dumped or replaced the essence because this will remain forever. A great and reputable name will be forgotten and everyone's legacy may not be echoed after a thousand years. Can one enunciate that his essence is lost? What is the parameter for essence? Can time be the basis or the quality of essence in order to accept its presence? One's identity may be lost but his contribution as product of transitions and innovations lives on. His contribution serves as a pillar of the evolution and development of the civilization. Why did heroes of the past endeavor to achieve freedom and foster "Bayanihan"? and why do the unsung heroes of today keep the fire of heroism alive while uplifting the moral standard from the rich heritage of culture and maxims of our society?

The abstract ideas of Plato became universal. What does it mean? The memories and images of individuality may fade but their essential substance will never be lost. However, it will no longer give credit on a particular individual but eventually be attributed on eternal form. The essence of man does not confine only to him as individual but rather constitute entire humanity [2]. The beneficiary of essence is not just the beholder nor its successors but the entire future and the civilization as a whole. Therefore, the legacy of man, as he created his image, defines himself and consequently constitutes the essence of humanity [2].

\section{SUMMARY AND CONCLUSION}

Legacy appears to be the stimulus of anxiety from the moment that man knows and feels that he exists. The consciousness on the occurrence of angst are: a) pastthat requires the affirmation of authentic self, b) futurethat requires one's potential as being thrown into the world and c) present condition- which is knowing that everyone dies. But among these three sums all the anxieties of man, his present situation is the severe condition of humanity finding a way out from a horrible ending.

Man creates a belief which is the deluded fancy that Nietzsche suggested to cast. This is convalescent that may configure man to surpass from the anxiety into the notion of death. This idea is nothing but hope for salvation afterlife. Given this way of healing from the past, new preachers of the society are much exaggerated preachers to deliberately do and catch sympathy for certain ambition. They made great chances to capture the many to make them pronounced new leaders of the community. Unfortunately, corruption continues to rot both political and religious systems of humanity. It affects the minds of the people, reshaping their morale and leading them to be impotent and dull. The deluded fancy of man acquired with perverted interpretation of the proclaimed preachers resulting to a drastic delusional belief or deception to man; leading the masses to despise their body and paralyze their capability. The notion that man will strive to achieve his fullest capacity lies to sentiments that he cannot totally exercise his freedom and potentials. In addition, it is unreasonable to despise the physical body that induces one and not to give importance to the worldly life. Indeed, it is impossible to think to live without the body that performs entirely. It is deluded into thinking to refute life and assume the real world that is absurd due to its inadequacy. If one gets despised the deficits of this world, then man will surely be in hallucination to achieve justice, essence and equality.

In the course of religious ecstasy, all practices and worship mechanism of the cults trigger toxins that control people to do the same. This activity appears the "process" of allowing man on how he transforms into a sudden absolute ecstasy. Apparently, if fancy is man's invented convalescent, hysteria is a method of eschewing or diverting one's anxiety into peculiar activity endowed with gratification, ecstasy and fulfillment. So, in dealing with someone's death, some religious cults accept the concept that death is not a kind of loss, but rather a sign of celebration and delight as if it was a new beginning of the genuine life. Guided by this concept, the family that has lost its loved one never feels sorrowful or grievous. This is the kind of faith that is now widely practiced by many religious guilds.

Indeed, to die with nothing at all will flow into nothingness. This nothingness is the fate of absurdity of being. Hence, it appears that what man can contribute to his temporary life is the legacy. As man acquired life, he also acquired his purpose. His legacy defines his essence in humanity. The physical body fades due to the inevitable death but the integrity, values and morals that a person has lived by never die. The mortality of being is impossible to hide as well as the facts of its limitations 
and temporalities, but the existence of his spirits will remain forever and this is about legacy. Legacy is the spirit that will echo until eternity. Death is life and it is not yet an ending, but rather a fresh beginning, so why should someone be anxious of it?

It is therefore concluded that the deluded fancy and ecstasy of man induced to despise his own body. This is a manifestation of total absurdity. Hence, the investigation falls in the conclusion that man is controlled by either his will or others' will to become a victim of both self and preachers. From the concepts presented about the notion on death, there is constant view that is absolute, man has been enslaved of his own absurdity and become a prey of the greedy beast. And the will of those extreme preachers of this generation continue to steal the rights and privileges of the masses, reshapes their morals and paralyzes the innocent ones.

\section{ACKNOWLEDGEMENTS}

The author would like to commemorate the members of his family who suffered from tragic death: his brother Randy (2007), mother Cholita (2018) and his newborn baby Avesta (2018).

\section{REFERENCES}

[1] Heidegger, Martin. Being and Time, Translated by John Macquarrie and Edward Robinson, Oxford UK: Blackwell Publishers Ltd., 1962.

[2] Sartre, Jean-Paul. Existentialism and Humanism, Translated and Introduction by Philip Mairet, London: Methuen \& Co. Ltd., 1966.

[3] Rousseau, Jean-Jacques, The Social Contract and The First and Second Discourses, Edited with an Introduction by Susan Dunn, New York: Yale University Press, 2002.

[4] Critical Analysis https://www2.southeastern.edu/Academics/Faculty/e lejeune/critique.htm.

[5] Nietzsche, Friedrich. Thus Spoke Zarathustra, Translated with an Introduction by R. J. Hollingdale, England: Penguin Books Ltd., 1961, 1969.

[6] Cooper, John M., Edited, Plato: Complete Works, Indianapolis, IN Hackett Publishing Company Inc., 1997.

[7] Sartre, Jean-Paul. Being and Nothingness: A Phenomenological Essay on Ontology, Translated and with an Introduction by Hazel E. Barnes, New York: Pocket Books, 1978.

[8] Bolaños, Paolo A., On Affirmation and Becoming: A Deleuzian Introduction to Nietzsche's Ethics and Ontology, UK: Cambridge Scholars Publishing, 2014
[9] Deleuze, Gilles. Nietzsche and Philosophy, Translated by Hugh Tomlinson, New York: Columbia University Press, 1983.

[10] Jung, Carl G., The Undiscovered Self, Translated from German by R.F.C. Hull, New York: A Division of Penguin Books USA Inc., 1957, 1958.

[11] Santiago, Patrick Neil M., Absurdmind: The Ten Shades of the Nature of Will, Tarlac City: RMC Publishing Haus, 2017.

[12] Jung, Carl G., M.-L.von Franz, Joseph L. Henderson, Jolande Jacobi, Aniela Jaffé. Man and his Symbols, New York: Doubleday \& Company Inc., 1964. 